\title{
Root Infections May Challenge Management of Invasive Phytophthora spp. in U.K. Woodlands
}

E. J. Fichtner and D. M. Rizzo, University of California, Davis 95616; and S. A. Kirk and J. F. Webber, Forest Research, Alice Holt Lodge, Farnham, Surrey GU10 4LH, United Kingdom \begin{abstract}
woodlands. Plant Dis. 95:13-18.
Because sporulation of Phytophthora ramorum and P. kernoviae on Rhododendron ponticum, an invasive plant, serves as primary inoculum for trunk infections on trees, $R$. ponticum clearance from pathogeninfested woodlands is pivotal to inoculum management. The efficacy of clearance for long-term disease management is unknown, in part due to lack of knowledge of pathogen persistence in roots and emerging seedlings. The main objectives of this work were to (i) investigate whether both pathogens infect $R$. ponticum roots, (ii) determine the potential for residual inoculum of $P$. kernoviae to infect $R$. ponticum seedlings in cleared woodlands, and (iii) assess potential for $R$. ponticum roots to support survival and transmission of $P$. kernoviae. Roots of $R$. ponti-
\end{abstract}

Abstract

Fichtner, E. J., Rizzo, D. M., Kirk, S. A., and Webber, J. F. 2011. Root infections may challenge management of invasive Phytophthora spp. in U.K.

cum were collected from both unmanaged and cleared woodlands and assessed for pathogen recovery. Both $P$. ramorum and $P$. kernoviae were recovered from asymptomatic roots of $R$. ponticum in unmanaged woodlands, and $P$. kernoviae was recovered from asymptomatic roots from seedlings in cleared woodland. Oospore production of $P$. kernoviae was observed in naturally infected $R$. ponticum foliage and in inoculated roots. Roots also supported P. kernoviae sporangia production. The results of this study suggest that post-clearance management of $R$. ponticum regrowth is necessary for long-term inoculum management in invaded woodlands.
Phytophthora kernoviae Brasier, Beales \& S.A. Kirk and $P$. ramorum Werres, de Cock \& Man in't Veld are exotic pathogens thought to have been introduced to Great Britain within the past 10 to 20 years (9). Both pathogens threaten the composition, health, and sustainability of U.K. mixed-species woodlands, planted woodland gardens, heritage gardens, and national plant collections. P. kernoviae is also an emerging threat to U.K. heathland, where it infects Vaccinium myrtillus, a key component of heathland habitat $(1,26)$. The geographic origin of each pathogen is unknown; however, $P$. kernoviae was recently recovered from soils in New Zealand forests (19). The risk of P. ramorum to forest health has already been realized in the Sudden Oak Death (SOD) epidemic in the western United States $(21,22)$.

$P$. ramorum was first described as a pathogen on ornamental nursery plants in Europe (27) but its later association with SOD exacted international concern for forest biosecurity. Surveys for $P$. ramorum in Great Britain were initiated in 2001 and the pathogen has since been found at hundreds of sites, in both nursery systems and woodlands $(6,17)$. As a result of the $P$. ramorum surveys, $P$. kernoviae, a previously unknown pathogen, was isolated concurrently from a bleeding lesion on European beech (Fagus sylvatica) and foliar lesions of Rhododendron ponticum (5), an invasive plant pervading unmanaged woodlands. $P$. ramorum and $P$. kernoviae cause extensive foliar necrosis and shoot dieback on $R$. ponticum and bleeding cankers on $F$. sylvatica, as well as other tree species $(6,9)$. Early surveys of disease incidence elucidated that the majority of infected trees are located within $2 \mathrm{~m}$ of infected $R$. ponticum, suggesting a role of $R$. ponticum in disease transmission (3). Bleed-

Corresponding author: J. F. Webber, E-mail: joan.webber@forestry.gsi.gov.uk Accepted for publication 7 September 2010.

doi:10.1094/PDIS-03-10-0236

(C) 2011 The American Phytopathological Society ing cankers on trees do not support sporulation of either pathogen but infected $R$. ponticum foliage supports sporulation of both pathogens and is the likely source of primary inoculum for new tree infections $(9,25)$.

Because $P$. ramorum and $P$. kernoviae rely on an invasive plant for transmission, removal of $R$. ponticum from infested woodlands is the initial step in implementing a disease management program $(11,25)$ (Fig. 1A and B). $R$. ponticum is generally an undesirable woodland invader, forming an impenetrable barrier which shades other vegetation and has limited value for shelter and game cover (9). The cost of $R$. ponticum clearance has been estimated in the range of millions of GBP (pound sterling) (25). Preliminary data suggest that inoculum levels in leaf litter and soil have dramatically decreased after $R$. ponticum clearance, and incidence of new tree infections in cleared woodlands is low $(9,25)$.

Both the invasive nature of $R$. ponticum and the persistence of both pathogens in litter and soil (25) pose a challenge to pathogen eradication. Even after herbicide treatment, $R$. ponticum regenerates from stumps and seed (25) and can rapidly recolonize a woodland. Phytophthora spp. infection of $R$. ponticum regrowth has been observed in cleared woodlands (Fig. 1C and D) (9) but the source of inoculum initiating these infections is unknown. The potential for $P$. kernoviae and $P$. ramorum to infect and persist in $R$. ponticum roots has yet to be explored; however, $P$. ramorum infects rhododendron roots in container culture $(18,24)$, and potting soil infested with chlamydospores can incite root infections $(7,8)$. $P$. kernoviae is homothallic and produces oospores in vitro; however, it is not yet known whether oospores are produced in planta and contribute to pathogen persistence in woodlands.

The development of post-clearance woodland management guidelines relies on a comprehensive understanding of the survival and transmission components of the disease and life cycles of these pathogens. Therefore, this article addresses the potential for (i) both pathogens to infect adventitious roots of $R$. ponticum, (ii) residual inoculum of $P$. kernoviae to infect $R$. ponticum seedlings in cleared woodlands, and (iii) P. kernoviae to produce spo- 
rangia on $R$. ponticum roots and oospores in $R$. ponticum roots and foliage.

\section{Materials and Methods}

Research locations. All field work was conducted in infested woodlands in Cornwall, southwest England. Three unmanaged woodlands containing dense, established $R$. ponticum were chosen for root excavation. Two of these unmanaged woodlands, located near Truro, were infested with $P$. kernoviae, and the third, near Penzance, was infested with $P$. ramorum. Another Truro-area woodland, cleared in 2004 of $R$. ponticum, was selected for excavation of emergent $R$. ponticum seedlings. All selected woodlands were heavily infested with either $P$. ramorum or P. kernoviae, and contained $F$. sylvatica with active infections. All laboratory work was conducted in Forest Research quarantine facilities at Alice Holt Lodge in Farnham, Surrey.

Phytophthora spp. recovery from adventitious roots. In May and November 2007, four sets of R. ponticum roots were excavated from each of the two $P$. kernoviae-infested woodlands and the single $P$. ramorum-infested woodland. Adventitious roots formed by layered stems were chosen to ensure that roots sampled were those of $R$. ponticum and not other woodland vegetation. At each point of layerage, the entire root mass was excavated, along with approximately 0.5 liter each of overlying leaf litter and rhizosphere soil, and five symptomatic attached leaves.

To isolate Phytophthora spp. from $R$. ponticum foliage, leaves were surface sterilized in $70 \%$ ethanol for $30 \mathrm{~s}$ (10), then rinsed three times in deionized (DI) water and blotted dry. Samples were excised along lesion margins and submerged in synthetic mucor agar (SMA), a selective medium containing pimaricin (0.01 g/liter), and rifamycin SV sodium salt (3.0 g/liter) (12). Leaf litter and soil samples were baited for Phytophthora spp. by saturating samples in DI water and floating 101 -cm-diameter $R$. catawbiense 'Cunningham's White' leaf disks on the water surface. After 7 days, leaf disks were retrieved, soaked in 30\% ethanol for $30 \mathrm{~s}$, rinsed in DI water, blotted dry, and placed on SMA amended with hymexazol (0.05 g/liter), pentachloronitrobenzene (PCNB; $0.025 \mathrm{~g} / \mathrm{liter})$, ampicillin (0.2 g/liter), nystatin $(50 \mu \mathrm{l} /$ liter), and rifampicin (0.01 g/liter). All putative Phytophthora spp. were then subcultured on carrot agar (CA) for morphological identification. These techniques for pathogen baiting, isolation, and identification were used throughout the study, unless otherwise stated. Isolations from foliage were submerged in SMA, whereas bait materials from soil and leaf litter were submerged in SMA amended with hymexazol, PCNB, ampicillin, nystatin, and rifamycin.

All roots were thoroughly washed with DI water to remove soil, then cut into approximately 3-cm segments. In May 2007, washed roots were incubated in moist chambers for $24 \mathrm{~h}$, then baited for Phytophthora spp. The root masses excavated in November 2007 were surface sterilized to ensure that Phytophthora spp. recovered by baiting resulted from root infections and not from propagules on the rhizoplane. Because fine roots are only a few cell layers thick and susceptible to disruption during surface sterilization, two surface sterilization techniques were used to enhance detection of root infections (24). Root masses were divided into two portions, with one portion incubated $5 \mathrm{~min}$ in $0.025 \% \mathrm{NaOCl}$ and the other in $30 \%$ ethanol for $30 \mathrm{~s}$ (23). After surface sterilization, all roots were rinsed three times in DI water, then incubated for $24 \mathrm{~h}$ in moist chambers before baiting.

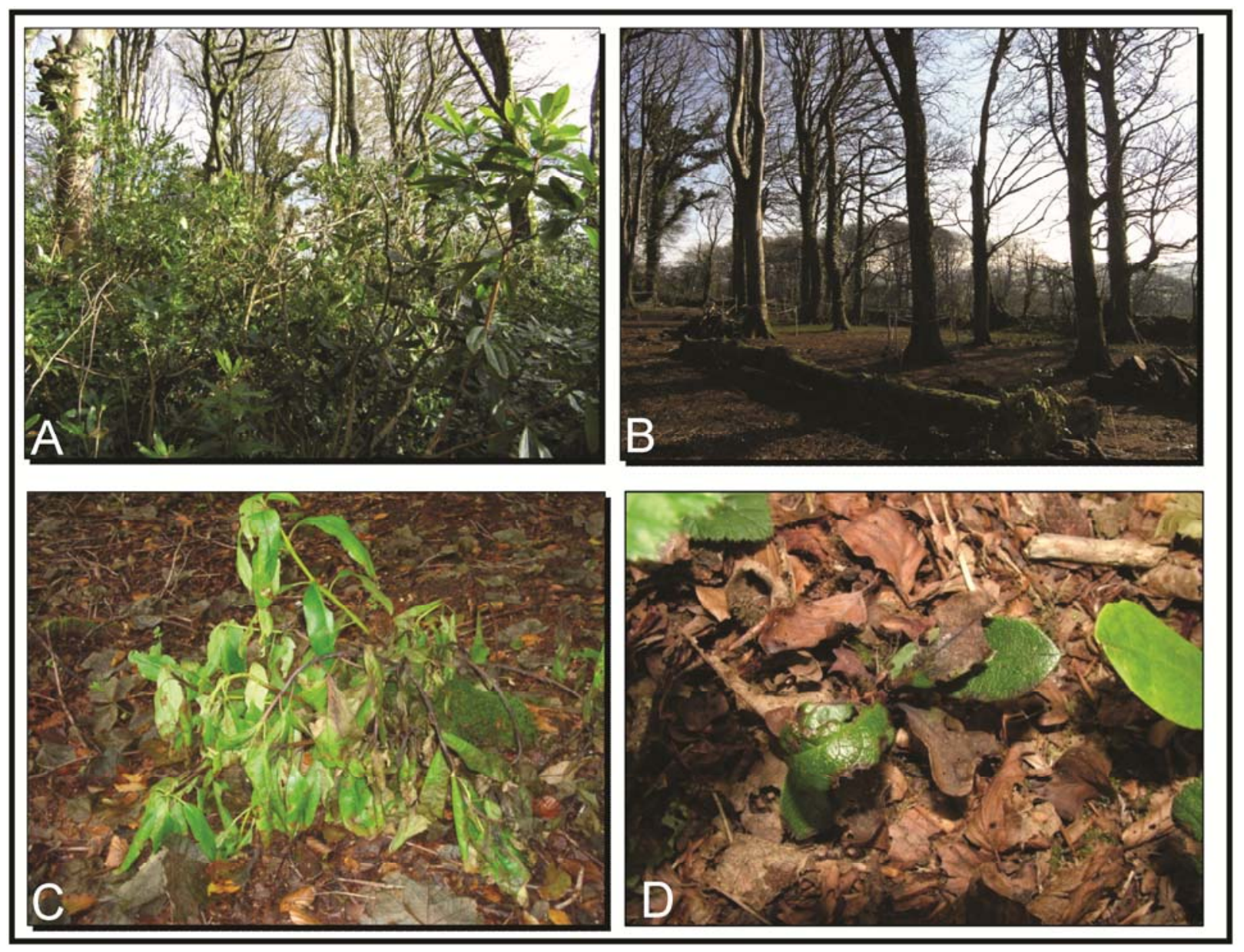

Fig. 1. Woodlands invaded with Rhododendron ponticum have been cleared of the invasive plant for management of Phytophthora kernoviae and $P$. ramorum. Infested woodland $\mathbf{A}$, before and $\mathrm{B}$, after clearance of $R$. ponticum. Both images were taken from the same location. (Images courtesy of A. Brown and C. Brasier). Post-clearance infection by $P$. kernoviae of $\mathbf{C}$, vegetative shoots and $\mathbf{D}$, seedlings. 
Phytophthora spp. recovery from seedlings. In May and November $2007, R$. ponticum seedlings and associated rhizosphere soil were collected from a $P$. kernoviae-infested woodland that had been cleared of $R$. ponticum in 2004. Unlike samples collected in uncleared woodlands, leaf litter was unavailable because it had been removed during $R$. ponticum clearance. In May 2007, $19 R$. ponticum seedlings were collected and roots were thoroughly washed, incubated in moist chambers for $24 \mathrm{~h}$, and then directly baited for Phytophthora spp. In November 2007, 30 seedlings were collected. Roots of 10 seedlings were baited without surface sterilization, roots of 10 seedlings were surface sterilized in $30 \%$ ethanol for $30 \mathrm{~s}$, and roots of 10 seedlings were surface sterilized for 5 $\min$ in $0.025 \% \mathrm{NaOCl}$. All roots were rinsed thoroughly after surface sterilization, then incubated for $24 \mathrm{~h}$ in moist chambers before baiting for Phytophthora spp.

Determination of sporangia production on roots. After bait leaf disks were removed from samples of both adventitious roots and seedling roots, roots were blotted dry and stored in moist chambers at $18^{\circ} \mathrm{C}$. Roots were stored until putative Phytophthora isolates grew out of leaf baits, generally 3 to 5 days after placing on selective medium. Roots giving rise to Phytophthora colonies from baits were then cleared and stained for microscopic observation. Because of the caducous nature of $P$. kernoviae sporangia (5), observation of sporangia attached to sporangiophores at the root surface was challenging, particularly after disruption during a staining procedure. Consequently, artificially inoculated roots were also used to determine the potential for roots to support sporulation. Roots of micropropagated rhododendron plantlets grown in axenic culture (plantlets donated by R. Smith, Duchy College, Cornwall) were utilized to enable observation of sporangia in the absence of other root-inhabiting fungi. Micropropagated roots of four plants were dipped in a $10^{4}$ zoospore $/ \mathrm{ml}$ suspension and then incubated for 10 days in moist chambers before clearing and staining for observation. The zoospore suspension was produced by growing two isolates (ROS SD8 and ROS SD9) of P. kernoviae on CA for 1 week at $18^{\circ} \mathrm{C}$ under a continuous lighting regime of $12 \mathrm{~h}$ of white light followed by $12 \mathrm{~h}$ of black light. Aliquots of DI water $(3 \mathrm{ml}$ each) were pipetted onto the surface of each colony and colonies were gently scraped with a glass rod to dislodge the sporangia. The spore suspension, a cocktail of two isolates, was then gathered into a beaker and refrigerated at $4{ }^{\circ} \mathrm{C}$ for $45 \mathrm{~min}$ to allow for zoospore release; then, zoospores were enumerated with a hemacytometer.

A modification of Koske's clearing and staining procedure (16) was used to render roots semitranslucent for visual observation. Roots were soaked in $2.5 \% \mathrm{KOH}$ for approximately $24 \mathrm{~h}$. Roots were rinsed three times in DI water, then acidified for $10 \mathrm{~min}$ in $1 \% \mathrm{HCl}$. The $\mathrm{HCl}$ was decanted and roots were next placed in $0.05 \%$ trypan blue stain and left overnight at room temperature. Trypan blue was then poured off and roots were incubated in a destain solution $(500 \mathrm{ml}$ of glycerin, $450 \mathrm{ml}$ of DI water, and $50 \mathrm{ml}$ of $1 \% \mathrm{HCl}$ ) for 2 days before viewing. Fine roots were placed on glass slides and observed under the compound microscope for sporangia. Images were captured using an Olympus BX51 microscope with an Olympus DP70 camera.

Determination of oospore production in $R$. ponticum foliage. A sequential approach was adopted to determine the potential for
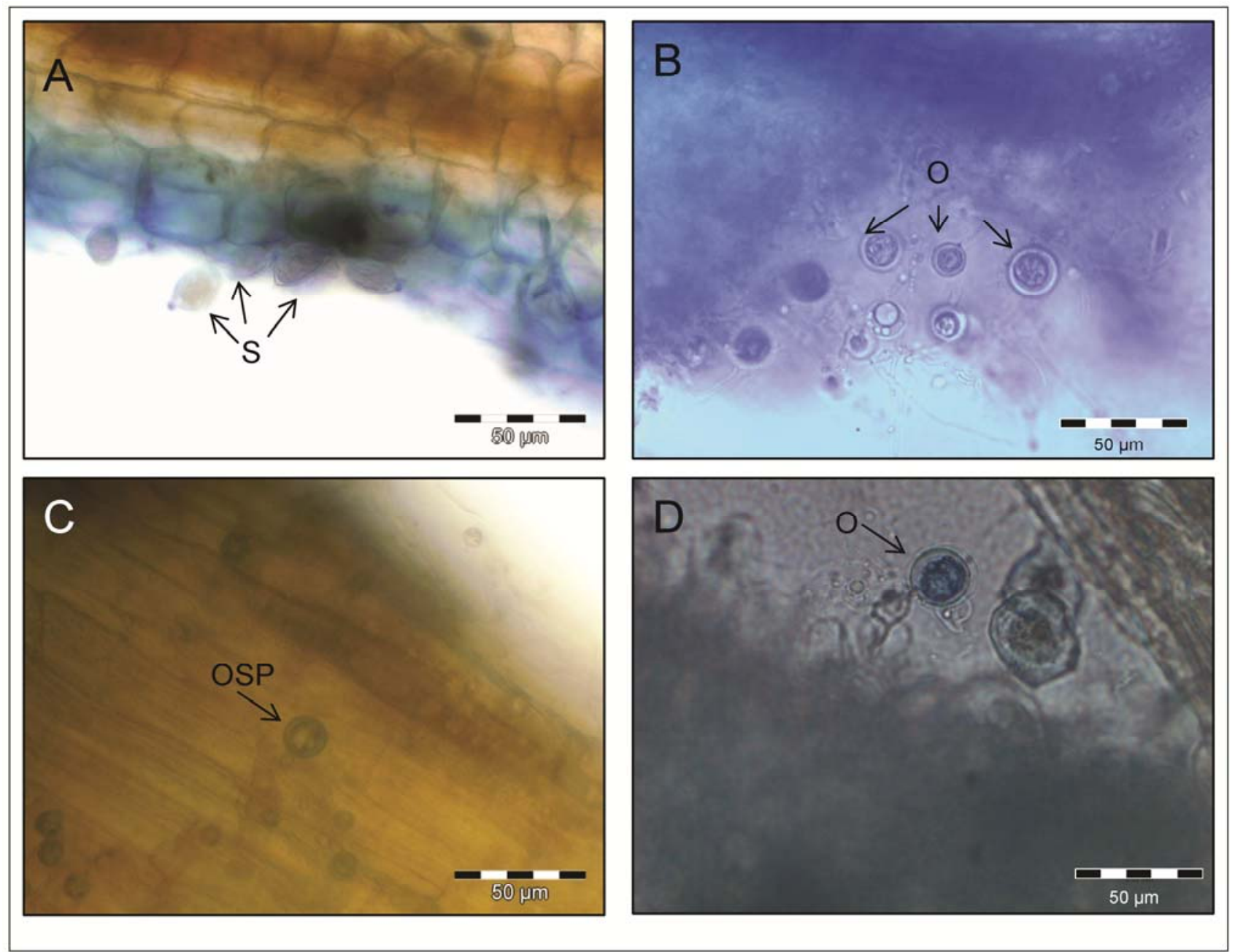

Fig. 2. A, Sporangia (S) of Phytophthora kernoviae on the root surface of an inoculated micropropagated rhododendron plant. B, Oogonia (O) of $P$. kernoviae on Rhododendron 'Cunningham's White' foliage used as bait material for detection of Phytophthora spp. in roots. C, Oospores (OSP) of P. kernoviae within inoculated roots of $R$. ponticum. $\mathrm{D}$, Oogonium $(\mathrm{O})$ of $P$. kernoviae within a naturally-infected $R$. ponticum leaf. Arrows indicate location of propagules within photos. 
oospore production in foliage. First, rhododendron leaf baits that yielded $P$. kernoviae in culture were removed from selective medium and then cleared using a modification of the aforementioned protocol (16). In addition to soaking the leaf disks in $\mathrm{KOH}$ overnight, disks were further cleared by incubation in $\mathrm{KOH}$ solution at $90^{\circ} \mathrm{C}$ for 20 to $30 \mathrm{~min}$ (16). After oospores were observed in bait leaf disks, naturally infected $R$. ponticum leaves were collected and cleared for determination of oospore production. Twenty symptomatic leaves were collected from one of the uncleared sites used in the adventitious roots study. Infection with $P$. kernoviae was confirmed by isolation; then, leaves were incubated at $4^{\circ} \mathrm{C}$ for approximately 4 weeks. Because conditions required for in planta oospore production are, as yet, unknown, the cool incubation was provided to increase the probability of oospore production and detection. Plant tissue was then cleared and stained using the same technique employed for the leaf disk baits.

Determination of oospore production in $R$. ponticum roots. The potential for roots to support oospore production was determined in artificially inoculated roots. In September 2008, roots of four $R$. ponticum plants were excavated from forest at Alice Holt Lodge (Farnham, Surrey), a site with no history of infestation with either P. kernoviae or P. ramorum. Root masses from each plant were washed thoroughly and then divided in half, and one half was surface sterilized in $0.025 \% \mathrm{NaOCl}$ for $5 \mathrm{~min}$, then rinsed. Using the aforementioned baiting procedure, roots were then assessed for natural Phytophthora infection. The remaining half of each root mass was divided into 10 4-cm-long segments. Root segments were dipped into a $10^{5}$ zoospore suspension of $P$. kernoviae, produced by the aforementioned technique, then incubated in moist chambers for 6 days. Roots were surface sterilized for $5 \mathrm{~min}$ in $0.025 \% \mathrm{NaOCl}$, rinsed thoroughly, and incubated in moist chambers for an additional $24 \mathrm{~h}$. Root segments were then cut in half; one half was placed in SMA for quantification of frequency of pathogen recovery and the other half was cleared and stained for

Table 1. Recovery of Phytophthora kernoviae from litter, soil, foliage, and adventitious roots of Rhododendron ponticum in two unmanaged woodlands

\begin{tabular}{|c|c|c|}
\hline \multirow[b]{2}{*}{ Site, source } & \multicolumn{2}{|c|}{ Frequency of $P$. kernoviae recovery ${ }^{\mathrm{a}}$} \\
\hline & May 2007 & October 2007 \\
\hline \multicolumn{3}{|l|}{ Site 1} \\
\hline Foliage $^{b}$ & $1 / 4$ & $4 / 4$ \\
\hline Litter $^{\mathrm{c}}$ & $4 / 4$ & $3 / 4$ \\
\hline Soil ${ }^{c}$ & $0 / 4$ & $0 / 4$ \\
\hline \multicolumn{3}{|l|}{ Roots $^{d}$} \\
\hline Non-surface sterilized & $3 / 4$ & NA \\
\hline $\mathrm{NaOCl}$ & NA & $3 / 4$ \\
\hline EtOH & NA & $2 / 4$ \\
\hline \multicolumn{3}{|l|}{ Site 2} \\
\hline Foliage ${ }^{b}$ & $0 / 4$ & $4 / 4$ \\
\hline Litter $^{\mathrm{c}}$ & $3 / 4$ & $3 / 4$ \\
\hline Soil ${ }^{\mathrm{c}}$ & $0 / 4$ & $0 / 4$ \\
\hline \multicolumn{3}{|l|}{ Roots $\mathrm{d}$} \\
\hline Non-surface sterilized & $2 / 4$ & NA \\
\hline $\mathrm{NaOCl}$ & NA & $4 / 4$ \\
\hline $\mathrm{EtOH}$ & NA & $3 / 4$ \\
\hline
\end{tabular}

${ }^{\text {a }} \mathrm{N} / \mathrm{A}=$ data not available.

${ }^{\mathrm{b}}$ Five symptomatic leaves were collected from each of four plants at each site. Leaves were surface sterilized in $70 \%$ ethanol and rinsed, and then symptomatic tissues were placed on synthetic mucor agar (SMA), for isolation of Phytophthora spp. (10).

${ }^{\mathrm{c}}$ Litter overlying adventitious roots and rhizosphere soil were collected from four $R$. ponticum plants at both sites. Litter and soil samples were baited for 7 days with rhododendron leaf disks. Leaf disks were then placed on amended SMA for isolation of Phytophthora spp.

d Roots sampled in May 2007 were not surface sterilized. Root masses collected in October 2007 were divided in half; one portion was surface sterilized in $30 \%$ ethanol $(\mathrm{EtOH})$ for $30 \mathrm{~s}$ and the second portion was surface sterilized in $0.025 \% \mathrm{NaOCl}$ for $5 \mathrm{~min}$ (23). All roots were rinsed thoroughly, incubated in moist chambers for $24 \mathrm{~h}$, then baited with rhododendron leaf disks for 7 days. Leaf disks were then placed on amended SMA for isolation of Phytophthora spp. observation of oospores. Inoculation of $R$. ponticum root segments with $P$. kernoviae was conducted twice.

\section{Results}

In May 2007, P. kernoviae was recovered from both adventitious root masses and leaf litter at sites 1 and 2 (Table 1) and $P$. ramorum was recovered from adventitious root masses and leaf litter at site 3 (Table 2). Similar results were observed in repeated root excavation in October 2007 (Tables 1 and 2); however, in October 2007, all roots were surface sterilized prior to baiting. Roots from sites 1 and 2 yielded $P$. kernoviae after surface sterilization with both the $\mathrm{NaOCl}$ and the ethanol (Table 2). At site 3, $P$. ramorum was recovered only in roots surface sterilized with $\mathrm{NaOCl}$ (Table 2). None of the excavated roots at any of the three sites showed symptoms of root rot. No Phytophthora spp. were baited from soils at the three sites. A shift in the population of Phytophthora spp. baited at site 3 was observed between May 2007 and October 2007 (Table 2). In May 2007, only P. ramorum was recovered at site 3; however, in October 2007, P. kernoviae was baited from two leaf litter samples, $P$. hibernalis was baited from one litter sample, and P. citricola was isolated from foliage of one plant (Table 2).

Of the 19 seedlings collected from a cleared woodland in May 2007, only 2 exhibited foliar symptoms of pathogen infection (Fig. 1D). Upon isolation, these foliar lesions were then confirmed to be infected with P. kernoviae (Table 3). P. kernoviae was baited from two soil samples and from roots of five seedlings (Table 3). The two seedlings containing foliar infections with P. kernoviae were also found to have P. kernoviae on the roots. All roots were asymptomatic, with no evidence of root rot or general necrosis.

In October 2007, of the 30 seedlings collected, only 3 seedlings contained foliar infection with P. kernoviae (Table 3). P. kernoviae was not baited from associated soil; however, the pathogen was baited from roots of 11 seedlings, including surface-sterilized roots (Table 3). All roots were asymptomatic and no other Phytophthora spp. were detected in the cleared woodland.

Sporangia production of $P$. kernoviae was observed on all inoculated micropropagated rhododendron roots (Fig. 2A). Prolific sporulation was observed on the root surface; however, no oogonia were observed. Sporangia of $P$. kernoviae were also observed on naturally infected roots of two $R$. ponticum seedlings and on ad-

Table 2. Recovery of Phytophthora ramorum from litter, soil, foliage, and adventitious roots of Rhododendron ponticum in an unmanaged woodland

\begin{tabular}{lcc}
\hline & \multicolumn{2}{c}{ Frequency of $\boldsymbol{P}$. kernoviae recovery } \\
\cline { 2 - 3 } Site 3 & May 2007 & October 2007 $^{\mathrm{a}}$ \\
\hline Foliage $^{\mathrm{b}}$ & $2 / 4^{*}$ & $3 / 4 \dagger$ \\
Litter $^{\mathrm{c}}$ & $4 / 4$ & $2 / 4 \dagger+$ \\
Soil $^{\mathrm{c}}$ & $0 / 4$ & $0 / 4$ \\
Roots $^{\mathrm{d}}$ & & \\
Non-surface sterilized & $1 / 4$ & $\mathrm{NA}$ \\
$\mathrm{NaOCl}$ & $\mathrm{NA}$ & $2 / 4$ \\
EtOH & $\mathrm{NA}$ & $0 / 4$ \\
\hline
\end{tabular}

${ }^{\mathrm{a}}$ N/A $=$ data not available; $*$ indicates $P$. citricola also isolated from foliage; $\dagger$ indicates $P$. kernoviae also isolated or baited from samples; and $\ddagger$ indicates $P$. hibernalis also baited from litter sample.

${ }^{b}$ Five symptomatic leaves were collected from each of four plants. Leaves were surface sterilized in $70 \%$ ethanol and rinsed, and then symptomatic tissues were placed on synthetic mucor agar (SMA) for isolation of Phytophthora spp. (10).

${ }^{c}$ Litter overlying adventitious roots and rhizosphere soil were collected from four $R$. ponticum plants. Litter and soil samples were baited for 7 days with rhododendron leaf disks. Leaf disks were then placed on amended SMA for isolation of Phytophthora spp.

${ }^{d}$ Roots sampled in May 2007 were not surface sterilized. Root masses collected in October 2007 were divided in half, and one portion was surface sterilized in 30\% ethanol (EtOH) for $30 \mathrm{~s}$ and the second portion was surface sterilized in $0.025 \% \mathrm{NaOCl}$ for $5 \mathrm{~min}$ (23). All roots were rinsed thoroughly, incubated in moist chambers for $24 \mathrm{~h}$, and then baited with rhododendron leaf disks for 7 days. Leaf disks were then placed on amended SMA for isolation of Phytophthora spp. 
ventitious roots from two plants excavated at site 2 . No oogonia or oospores were observed on naturally infected roots.

Oogonia of P. kernoviae were observed on all colonized $R$. $c a$ tawbiense Cunningham's White leaf disks used as baits (Fig. 2B). Oospores were also observed in several artificially inoculated roots of $R$. ponticum (Fig. 2C); however, the number of oospores produced per root segment was not recorded. An oogonium was observed in one naturally infected $R$. ponticum leaf (Fig. 2D). Uninoculated roots of $R$. ponticum yielded no other Phytophthora spp., indicating that the observed oospores were the result of $P$. kernoviae infection and colonization. When inoculated root segments were placed on SMA for confirmation of colonization by $P$. kernoviae, the pathogen was recovered from $100 \%$ of root segments in both inoculations.

\section{Discussion}

The results of this study reveal an underground component of the disease cycles of both $P$. ramorum and P. kernoviae in invaded U.K. woodlands. The recovery of both pathogens from surfacesterilized $R$. ponticum roots suggests that the pathogens have the ability to infect and colonize roots. The fact that all root infections were completely asymptomatic is consistent with the observations of Parke and Lewis (18), Tjosvold et al (24), and Riedel (20). This is the first report of root infections of $P$. ramorum and $P$. kernoviae on $R$. ponticum, and the first report of root infections of $P$. kernoviae on any host. Less is known of the life and disease cycles of $P$. kernoviae because it is a more recently described pathogen than $P$. ramorum and is currently limited to causing forest disease in the United Kingdom. The fact that both pathogens cause asymptomatic root infections is of pivotal concern because such infections can escape the visual observation of regulators and inspectors. Asymptomatic root infections offer a hidden pathway of pathogen transmission and persistence in both woodlands undergoing disease management operations and containerized nursery plants being distributed over large geographic areas.

Infected foliage of $R$. ponticum tends to abscise (2), depositing a layer of inoculum on the forest floor. Our results demonstrate the potential for $R$. ponticum leaves to harbor oospores of $P$. kernoviae, and other work has demonstrated that rhododendron leaves harbor chlamydospores of $P$. ramorum $(13,14)$. The deposition of these survival structures on the forest floor does, in part, explain the

Table 3. Recovery of Phytophthora kernoviae from roots and foliage of Rhododendron ponticum seedlings and associated rhizosphere soil in a managed woodland site ${ }^{\mathrm{a}}$

\begin{tabular}{lcc}
\hline & \multicolumn{2}{c}{ Frequency of $\boldsymbol{P}$. kernoviae recovery $^{\mathbf{b}}$} \\
\cline { 2 - 3 } & May 2007 & October 2007 \\
\hline Foliage $^{\mathrm{c}}$ & $2 / 19$ & $3 / 30$ \\
Soil $^{\mathrm{d}}$ & $2 / 19$ & $0 / 30$ \\
Roots $^{\mathrm{e}}$ & & \\
Non-surface sterilized & $5 / 19$ & $5 / 10$ \\
NaOCl & $\mathrm{NA}$ & $3 / 10$ \\
EtOH & $\mathrm{NA}$ & $3 / 10$ \\
\hline
\end{tabular}

a Woodland was cleared of $R$. ponticum in 2004 for management of $P$. kernoviae.

${ }^{\mathrm{b}}$ In May and October 2007, 19 and 30 seedlings, respectively, were excavated from the managed woodland site. N/A = data not available.

${ }^{c}$ Leaves were surface sterilized in $70 \%$ ethanol and rinsed, and then symptomatic tissues were placed on synthetic mucor agar (SMA) for isolation of Phytophthora spp. (10).

${ }^{\mathrm{d}}$ Soil was dislodged from roots, and then samples were individually baited with rhododendron leaf disks for 7 days. Leaf disks were then placed on amended SMA for isolation of Phytophthora spp.

${ }^{\text {e }}$ Roots collected in May 2007 were not surface sterilized. Of the 30 seedlings collected in October 2007, 10 roots remained non-surface sterilized, 10 were surface sterilized in $0.025 \% \mathrm{NaOCl}$ for $5 \mathrm{~min}(23)$, and 10 were surface sterilized in $30 \%$ ethanol (EtOH) for $30 \mathrm{~s}$. After surface sterilization, all roots were rinsed and then incubated in moist chambers for $24 \mathrm{~h}$ before baiting. Roots were baited for 7 days with rhododendron leaf disks and leaf disks were placed on amended SMA for detection of Phytophthora spp. distribution of inoculum detected in unmanaged woodlands. In unmanaged woodlands, $P$. ramorum and $P$. kernoviae were found in attached leaves, litter, and roots but not in soil. Considering that adventitious roots form at the leaf litter surface and grow through the infested leaf litter into underlying soil, it is likely that the leaf litter serves as primary inoculum for root infections.

The finding of root and foliar infections in $R$. ponticum seedlings in cleared woodland suggests that $P$. kernoviae may persist several years after initial $R$. ponticum clearance, and underscores the import of post-clearance woodland management for disease control. In the absence of $R$. ponticum, the most likely sources of primary inoculum in cleared woodland are residual propagules in soil and plant debris. Though $P$. kernoviae has been known to produce abundant oogonia in vitro, this is the first report of in planta oospore production. Oospores produced in $R$. ponticum roots and foliage may serve as survival structures in soil. Additionally, roots may support polycyclic sporulation, thus producing sporangia near the soil surface which can then be splash dispersed to aboveground plant parts or serve as primary inoculum for new root infections. In support of this hypothesis, 3 years after $R$. ponticum clearance, a new bleeding canker on $F$. sylvatica was observed near the soil line, suggestive of infection by rain-splashed soil inoculum.

The results of this work underscore the need for continued woodland management for years after initial $R$. ponticum clearance. The tenacity of $R$. ponticum regrowth, from both roots and the residual seed bank, serves as a persistent challenge for land managers, while $R$. ponticum vegetation must be continuously removed from woodlands to insure the success of the initial investment in clearance. Though preliminary data suggest that $R$. ponticum clearance reduces woodland populations of $P$. ramorum and $P$. kernoviae (25), it is yet presumptuous to assume that $R$. ponticum clearance may result in pathogen eradication. The observation of asymptomatic root infections on rhododendron opens the possibility that these pathogens may escape notice in cleared woodlands, causing asymptomatic infections on other woodland plants.

While focusing on effective management of these pathogens in U.K. woodlands, we must also consider the potential global impacts of introduction of $P$. ramorum and $P$. kernoviae to other ecosystems. For example, Brasier (4) suggests consideration of the potential impact of $P$. ramorum and $P$. kernoviae on $R$. ponticumLaurus-Quercus ecosystems in Southern Spain, a system where $R$. ponticum is a native plant. Preliminary studies suggest that $P$. kernoviae may threaten North American native plants, including rhododendron and California bay laurel (15). The key to preservation of natural systems is to prevent pathogen spread; however, the prevalence of asymptomatic root infections may allow pathogens to move undetected, perhaps allowing invasive pathogens to become established in new ecosystems before mitigation strategies can be effectively considered and employed.

\section{Acknowledgments}

Funding for this research was provided by The Royal Society, the United States Forest Service, Pacific Southwest Research Station, and the United States Department of Agriculture Animal and Plant Health Inspection Service PPQ Center for Plant Health Science and Technology. We thank R. Smith and Duchy College for donating micropropagated rhododendron plantlets; S. Denman for providing isolates of P. kernoviae; D. Beattie for assistance with microscopy; A. Brown and C. Brasier for providing photographs; B. Jones and A. Whybrow for assistance at field sites in Cornwall; and S. Frankel, K. Aram, and two anonymous reviewers for their assistance in revising this manuscript.

\section{Literature Cited}

1. Beales, P. A., Giltrap, P. G., Payne, A., and Ingram, N. 2008. A new threat to UK heathland from Phytophthora kernoviae on Vaccinium myrtillus. Plant Pathol. 58:393.

2. Beales, P. A., Lane, C. R., Barton, V. C., and Giltrap, P. M. 2006. Phytophthora kernoviae on ornamentals in the UK. OEPP/EPPO Bull. 36:377379.

3. Brown, A., Brasier, C., and Webber, J. 2006. Aetiology and distribution of Phytophthora kernoviae and P. ramorum stem lesions on European beech in southwest England. Pages 139-141 in: Progress in Research on Phytophthora Diseases of Forest Trees. Proc. Third Int. IUFRO Working Party 
S07.02.09, Freising, Germany. C. Brasier, T. Jung, and W. Osswald eds. Forest Research, Farnham, Surrey, UK.

4. Brasier, C. M. 2008. The biosecurity threat to the UK and global environment from international trade in plants. Plant Pathol. 57:792-808.

5. Brasier, C. M., Beales, P. A., Kirk, S. A., Denman, S., and Rose, J. 2005. Phytophthora kernoviae sp. nov., an invasive pathogen causing bleeding stem lesions on forest trees and foliar necrosis of ornamentals in the UK. Mycol. Res. 109:853-859.

6. Brasier, C. M., Denman, S., Rose, J., Kirk, S. A., Hughes, K. J. D., Griffin, R. L., Lane, C. R., Inman, A. J., and Webber, J. F. 2004. First report of ramorum bleeding canker on Quercus falcata, caused by Phytophthora ramorum. Plant Pathol. 53:804.

7. Colburn, G., Sechler, K., and Shishkoff, N. 2006. Survivability and pathogenicity of Phytophthora ramorum chlamydospores in soil. (Abstr.) Phytopathology 95:S20.

8. Colburn, G. C., and Shishkoff, N. 2006. Density of Phytophthora ramorum chlamydospores in soil necessary to cause infection. (Abstr.) Phytopathology 96:S25.

9. Defra. 2008. Consultation on future management of risks from Phytophthora ramorum and Phytophthora kernoviae. Department for Environment, Food and Rural Affairs, London. www.defra.gov.uk/corporate/ consult/phytophthora-ram-kern/

10. Denman, S., Kirk, S. A., Moralejo, E., and Webber, J. F. 2009. Phytophthora ramorum and Phytophthora kernoviae on naturally infected asymptomatic foliage. Forest Research. Journal compilation. OEPP/EPPO Bull. 39:105-111.

11. Denman, S., Kirk, S. A., and Whybrow, A. 2009. Investigating the potential of disease control practices for integrated management of Phytophthora kernoviae on mature magnolias in the United Kingdom. Pages 246-247 in: Phytophthoras in Forests and Natural Ecosystems, Proc. Fourth Meeting Int. Union For. Res. Organ. (IUFRO) Working Party, Monterey, CA. Gen. Tech. Rep. PSW-GTR-221. E.M.

12. Elliott, C. G., Hendrie, M. R., and Knights, B. A. 1966. The sterol requirement of Phytophthora cactorum. J. Gen. Microbiol. 42:425-435.

13. Fichtner, E. J., Lynch, S. C., and Rizzo, D. M. 2007. Detection, distribution, survival, and sporulation of Phytophthora ramorum in a California redwood-tanoak forest soil. Phytopathology 97:1366-1375.

14. Fichtner, E. J., Lynch, S. C., and Rizzo, D. M. 2009. Survival, dispersal, and soil-mediated suppression of Phytophthora ramorum in a California redwood-tanoak forest. Phytopathology 99:608-619.

15. Fichtner, E. J., Rizzo, D. M., Kirk, S., and Webber, J. 2009. Epidemiology of Phytophthora kernoviae in UK woodlands and heathland and risk to North American forests. (Abstr.) Phytopathology 99:S35.

16. Koske, R. E., and Gemma, J. N. 1989. A modified procedure for staining roots to detect VA-mycorrhizas. Mycol. Res. 92:486-488.
17. Lane, C. R., Beales, P. A., Hughes, K. J. D., Griffin, R. L., Munro, R. L., Brasier, C. M., and Webber, J. F. 2003. First outbreak of Phytophthora ramorum in England on Viburnum tinus. Plant Pathol. 52:414.

18. Parke, J. L., and Lewis, C. 2007. Root and stem infection of Rhododendron from potting medium infested with Phytophthora ramorum. Plant Dis. 91:1265-1270.

19. Ramsfield, T. D., Dick, M. A., Beever, R. E., and Horner, I. J. 2009. Phy tophthora kernoviae-of southern hemisphere origin? Pages 47-53 in: Phyophthoras in Forests and Natural Ecosystems, Proc. Fourth Meet. Int. Union For. Res. Organ. (IUFRO) Working Party, Monterey, CA. Gen. Tech Rep. PSW-GTR-221. E. M. Goheen and S. J. Frankel, eds. U. S. Dep. Agric. For. Serv. Pac. Southwest Res. Stn. Albany, CA.

20. Riedel, M., Wagner, S., Götz, M., Belbahri, L., Lefort, F., and Werres, S. 2009 Phytophthora ramorum tissue colonization studied with fluorescence microscopy. Page 315 in: Phytophthoras in Forests and Natural Ecosystems, Proc. Fourth Meet. Int. Union For. Res. Organ. (IUFRO) Working Party, Monterey, CA. Gen. Tech. Rep. PSW-GTR-221. E. M. Goheen and S. J. Frankel, eds. U. S. Dep. Agric. For. Serv. Pac. Southwest Res. Stn. Albany, CA.

21. Rizzo, D. M., Garbelotto, M., Davidson, J. M., Slaughter, G. W., and Koike, S. T. 2002. Phytophthora ramorum as the cause of extensive mortality of Quercus spp. and Lithocarpus densiflorus in California. Plant Dis. 86:205214.

22. Rizzo, D. M., Garbelotto, M., and Hansen, E. M. 2005. Phytophthora ramorum: integrative research and management of an emerging pathogen in California and Oregon forests. Annu. Rev. Phytopathol. 43:309-335.

23. Shishkoff, N. 2007. Persistence of Phytophthora ramorum in soil mix and roots of nursery ornamentals. Plant Dis. 91:1245-1249.

24. Tjosvold, S. A., Chambers, D. L., Fichtner, E. J., Koike, S. T., and Mori, S. R. 2009. Disease risk of potting media infested with Phytophthora ramorum under nursery conditions. Plant Dis. 93:371-376.

25. Webber, J. F. 2009. Management of Phytophthora kernoviae and $P$ ramorum in Southwest England. Pages 177-183 in: Phytophthoras in Forests and Natural Ecosystems, Proc. Fourth Meet. Int. Union For. Res. Or gan. (IUFRO) Working Party, Monterey, CA. Gen. Tech. Rep. PSW-GTR 221. E. M. Goheen and S. J. Frankel, eds. U. S. Dep. Agric. For. Serv. Pac. Southwest Res. Stn. Albany, CA.

26. Webber, J., Brasier, C., Kirk, S., Denman, S., and Jones, B. Growing threat posed by Phytophthora kernoviae to native heathland ecosystems in Britain. In: Proc. Sudden Oak Death Fourth Sci. Symp. Gen. Tech. Rep. PSW-GTR229. S. J. Frankel, J. K. Kliejunas, and K. M. Palmieri, tech. coord. U. S. Dep. Agric. For. Serv. Pac. Southwest Res. Stn. Albany, CA. In press.

27. Werres, S., Marwitz, R., Man In't Veld, W. A., De Cock W. A. M., Bonants, P. J. M., De Weerdt, K., Ilieva, E., and Baayen, R. P. 2001. Phytophthora ramorum sp. Nov., a new pathogen on Rhododendron and Viburnum. Mycol. Res. 105:1155-1165. 